\title{
Resistance to Tomato chlorosis virus in Wild Tomato Species that Impair Virus Accumulation and Disease Symptom Expression
}

\author{
Elena García-Cano, Jesús Navas-Castillo, Enrique Moriones, and Rafael Fernández-Muñoz
}

Instituto de Hortofruticultura Subtropical y Mediterránea "La Mayora”, Universidad de Málaga-Consejo Superior de Investigaciones Científicas (IHSM-UMA-CSIC), Estación Experimental "La Mayora", 29750 Algarrobo-Costa, Málaga, Spain. Accepted for publication 30 January 2010.

\begin{abstract}
García-Cano, E., Navas-Castillo, J., Moriones, E., and Fernández-Muñoz, R. 2010. Resistance to Tomato chlorosis virus in wild tomato species that impair virus accumulation and disease symptom expression. Phytopathology 100:582-592.

Tomato chlorosis virus (ToCV) (genus Crinivirus, family Closteroviridae) is an emerging threat to tomato crops worldwide. Although symptoms on fruits are not obvious, yield losses occur through decreased fruit size and number. Control of ToCV epidemics is difficult because the virus is transmitted by several whitefly vector species and its relatively wide host range facilitates establishment in local wild reservoirs. Therefore, breeding for ToCV resistance offers the best control alternative. However, no sources for resistance are available thus far. Here, a screen

of tomatoes and wild species relatives was performed in search of ToCV resistance. Two sources of resistance to ToCV were identified in this work, lines '802-11-1' and '821-13-1', each derived by two self-pollinations from ToCV asymptomatic plants of the population 'IAC CN RT' (derived from an interspecific hybrid Solanum lycopersicum $\times S$. peruvianum accession LA0444) and accession LA1028 (S. chmielewskii), respectively. The resistance was expressed by impairing virus accumulation and disease symptom expression, both under natural infection and after challenging with $\mathrm{ToCV}$ in controlled inoculations. Genetic control of resistance to ToCV infection in '821-13-1' was conferred by a major locus with mainly additive effects but also partial dominance for higher susceptibility. Also, an additive $\times$ dominance epistatic interaction with at least one additional gene was evident.
\end{abstract}

Tomato (Solanum lycopersicum L., syn. Lycopersicon esculentum Mill.) is one of the major vegetable crops worldwide. However, the occurrence of epidemics of viral diseases greatly limits sustainable production. Thus, from the early 1990s, epidemics of the criniviruses (genus Crinivirus, family Closteroviridae) Tomato chlorosis virus (ToCV) and Tomato infectious chlorosis virus (TICV) are emerging worldwide causing severe damage to tomato production $(15,57,58)$. ToCV outbreaks are frequent in many parts of the world including the Americas $(3,35$, $53,58)$, Europe $(2,14,30,39)$, Africa and nearby islands $(13,19$, 26,36), the Middle East $(1,49)$, and Asia $(50,52)$. ToCV is a phloem-limited virus that is transmitted by three whitefly species (Hemiptera: Aleyrodidae), Bemisia tabaci Gennadius, Trialeurodes vaporariorum Westwood, and T. abutilonea Haldeman (54). Early symptoms of ToCV infections in tomato consist of light green polygonal patches on older leaves that evolve to interveinal yellowing resembling a magnesium nutrient deficiency. Also, bronzing and red patches often occur within the yellowed areas and the leaves become thickened and crispy with the margins curled slightly upward. Symptoms develop first on lower leaves and gradually progress toward the growing tip. Although no obvious symptoms are observed on fruits, flower abortion can occur and plant yellowing is accompanied by a decline in vigor that can result in reduced fruit size and delayed ripening, altogether reducing commercial yields. Severity of symptoms and yield losses vary depending on the cultivar and the time of infection. In Spain, outbreaks of ToCV in tomato have been

Corresponding author: E. Moriones; E-mail address: moriones@eelm.csic.es

* The $\boldsymbol{e}$-Xtra logo stands for "electronic extra" and indicates that the online version contains a table shows the results of screenings performed to seek for ToCV resistance in tomato germplasm.

doi:10.1094/PHYTO-100-6-0582

(C) 2010 The American Phytopathological Society alarming since 1997 and are associated with B. tabaci infestations (39).

The genome of ToCV consists of two positive-sense singlestranded RNA components encapsidated as long flexuous virions of 800 to $850 \mathrm{~nm}$ in length. RNA1 contains four open reading frames (ORFs), the largest of which encodes proteins associated with virus replication, and RNA2 contains nine ORFs encoding proteins associated with functions including virus encapsidation, movement, and whitefly transmission $(31,32,55)$.

Emergence of ToCV epidemics in many areas throughout the world is a cause of concern for tomato production not only because of direct damage but also because of synergistic interactions with other viruses $(17,39)$. Moreover, concerns exist because global warming might result in the emergence of ToCV into production regions that currently are free of this virus, as predicted for other vector-borne viruses $(23,45)$. Once ToCV is introduced into a new area, its broad vector transmissibility and substantially wide host range $(12,54)$ make it difficult to control and eradicate. So far the control of ToCV epidemics is preventive, mainly based on cultural practices to reduce whitefly pressure, but with limited success. Moreover, in many areas intensive insecticide treatments against whiteflies have resulted in the development of resistant populations $(5,6)$. Then, the use of genetic resistance to the virus is an attractive control alternative. However, no information is available about the existence of sources of resistance, which are needed to develop resistant commercial cultivars. Cultivated tomato displays only limited variation for disease resistance, yet wild species relatives are a useful source of variation for improving tomato (47). The objectives of this present work were (i) to detect sources of genetic resistance to ToCV through a germplasm screen in a collection of tomato cultivars and wild species of Solanum section Lycopersicon, (ii) to characterize the resistances found in a number of accessions, and (iii) to study the mode of inheritance of resistance of the most promising plant materials. 


\section{MATERIALS AND METHODS}

Germplasm screen. The genotypes used in this study were from the La Mayora-CSIC seedbank in which most of the wild species accessions are either from their own collections in Andean regions (PE accessions) or from collections maintained in the C.M. Rick Tomato Genetics Resource Center (LA accessions) and the USDA-ARS National Plant Germplasm System (PI accessions). One hundred and forty-five genotypes of tomato (including heirloom, landraces, released varieties, breeding lines, and $\mathrm{F}_{1}$ commercial hybrids), 14 accessions of $S$. lycopersicum var. cerasiforme Dunal, 13 accessions of S. pimpinellifolium L., 4 of S. galapagense S. Darwin and Peralta, 2 of S. chmielewskii (C.M. Rick et al.) D.M. Spooner et al., 11 of $S$. neorickii (C.M. Rick et al.) D.M. Spooner et al., 17 of $S$. habrochaites S. Knapp \& D.M Spooner, 10 of $S$. pennellii Correll, 13 of $S$. chilense (Dunal) Reiche, 4 of $S$. arcanum Peralta, 3 of $S$. corneliomulleri J.F. Macbr., 3 of $S$. huaylasense Peralta, and 8 of S. peruvianum L. were screened in the present study. In addition, the openpollinated tomato $\mathrm{cv}$. Moneymaker and the commercial tomato $\mathrm{F}_{1}$ hybrid 'Rambo' (Syngenta Seeds) were used as susceptible controls in all the screenings.

Field screenings for ToCV resistance under natural infection conditions were conducted in a plastic house at La Mayora-CSIC in which entrance of infected whiteflies from external sources occurred via lateral open windows. Trials were conducted during the springs of 2001 to 2004 in a region where ToCV infections regularly occur (39) and during periods when ToCV infections were prevalent in tomato. No insecticide treatments were given during the field trials in order to favor virus infection. Previous experience indicates that under these conditions ToCV infections occur following spread from infected commercial tomato crops in the surrounding areas. Healthy seedlings were grown in an insectproof glasshouse and then plants were transplanted in the plastic house at the four-leaf growth stage. The plastic house was divided in two blocks and in each block one plot of each tested genotype and two plots of susceptible control genotypes were randomly distributed. A plot consisted of five plants of the same genotype. The within-row and between-row spacing was $0.6 \mathrm{~m}$ and $1.5 \mathrm{~m}$, respectively. Plants in the plots were inspected for ToCV symptoms at 2-week intervals starting 2 months after transplanting, for a total of two (2001) to three (2002 to 2004) times per season. Disease severity was rated according to the scale indicated below. For those accessions exhibiting variability for ToCV-like symptom development, plants with mild or no symptoms were selfpollinated or sib-crossed and the progenies evaluated in the following trial to determine if this behavior was associated with environmental or genetic effects. The most promising inbred lines, sib-crosses and accessions exhibiting resistance under natural inoculation conditions were then selected for further evaluation by controlled inoculation of ToCV.

Characterization of ToCV resistance by controlled inoculation. For controlled virus inoculation of inbred lines, sib-crosses and accessions, the ToCV isolate Pl-1-2 was used. This isolate was obtained from a naturally infected tomato plant collected during 1997 in Málaga (southern Spain) from a commercial tomato crop and maintained at La Mayora-CSIC in tomato cv. Moneymaker by periodic transmission with $B$. tabaci. Whiteflymediated inoculations were performed using B. tabaci biotype Q individuals that were reared on melon (Cucumis melo L. cv. ANC42, La Mayora-CSIC seedbank collection) in insect-proof screened cages. Test plants were grown in a growth chamber $\left(25^{\circ} \mathrm{C}\right.$ day and $20^{\circ} \mathrm{C}$ night, $70 \%$ relative humidity, with a $16 \mathrm{~h}$ photoperiod at $250 \mu \mathrm{mol} \mathrm{s}{ }^{-1} \mathrm{~m}^{-2}$ photosynthetically active radiation). Virus source plants were susceptible tomato cv. Moneymaker plants inoculated approximately 30 days earlier with ToCV. For virus inoculation, viruliferous whiteflies were obtained by mass feeding of healthy B. tabaci biotype $\mathrm{Q}$ adults on ToCV- infected tomato source plants within insect-proof cages for a $48 \mathrm{~h}$ acquisition access period. Following virus acquisition, different inoculation methodologies were performed. For mass whitefly inoculation, healthy test plants (three-leaf growth stage) grown in seedling trays were caged in insect-proof screened cages with at least 40 viruliferous whiteflies per plant for a $48 \mathrm{~h}$ inoculation access period (IAP). For individual whitefly inoculation of plants, clip-on cages containing 40 viruliferous whiteflies were used on each test plant (three-leaf growth stage) for a 48 h IAP. Finally, for inoculation with extremely high ToCV pressure using whiteflies, test plants (three-leaf growth stage) were continuously inoculated during 15 days as in the mass inoculations, but releasing viruliferous whiteflies every 3 days for a total of about 400 viruliferous whiteflies per plant at the end of the IAP. Following IAP, the plants were sprayed with imidacloprid (Confidor, Bayer A.G., Leverkusen, Germany). Then, plants were maintained until analyzed either in a growth chamber or transplanted into $16 \mathrm{~m}^{2}$ field plots protected with whitefly-proof screen nets $(10 \times 22$ threads $\left./ \mathrm{cm}^{-2}\right)$, treating biweekly with imidacloprid and piriproxifen (Atominal, Sumitomo Chemical Co. Ltd., Japan). Plants were evaluated weekly for symptom development and virus presence as explained below. Uninoculated plants were included in every experiment for each genotype tested following the same procedures but using virus-free whiteflies. Controlled graft inoculations were conducted in an insect-proof glasshouse using as scion a stem piece containing a leaf with a bud from a healthy test plant which was grafted onto a ToCV-infected 'Moneymaker' rootstock plant. Also, when required, double-graft assays were conducted. In the latter case, a 5-cm-long stem piece of the healthy test plant was used as intergraft by grafting it on a ToCV-infected 'Moneymaker' rootstock plant. Then, after 10 days it was subsequently top-grafted with a scion from a healthy 'Moneymaker' plant. As controls, equivalent grafted plants were obtained, but using 'Moneymaker' as test plant. Five replicated plants were obtained in each case in an insect-proof greenhouse. The most promising plant materials from these experiments of controlled virus inoculation were then selected for the study of genetics of resistance.

Quantitative genetic analysis of ToCV resistance. Two inbred lines exhibiting ToCV resistance had been derived from the two most consistent sources of resistance found. The line '821-13-1' was obtained after two selfing and selection steps for ToCV resistance from the $S$. chmielewskii accession LA1028. The line '802-11-1' was obtained the same way from the accession 'IAC CN RT'. It is worth mentioning that accession 'IAC CN RT' comprises a phenotypically variable tomato population derived from an interspecific hybrid $S$. lycopersicum $\times S$. peruvianum LA0444 (29) that was achieved via embryo rescue (48). Then, '821-13-1' and '802-11-1' were attempted to be crossed with the susceptible tomato cv. Moneymaker, monitoring pollen growth in the pistils (see below). Only the cross with the S. chmielewskii line could be achieved and thus, the inheritance of its resistance to ToCV was studied with a family of generations of this cross. Pollen of '821-13-1' was used to pollinate 'Moneymaker' pistils to obtain the interspecific $F_{1}$ hybrid. A single $F_{1}$ plant was selfpollinated to provide the $\mathrm{F}_{2}$ generation and used to obtain backcrosses to the resistant $\left(\mathrm{F}_{1} \times\right.$ ' $821-13-1$ ', $\left.\mathrm{BC}_{1} \mathrm{R}\right)$ and to the susceptible ('Moneymaker' $\times \mathrm{F}_{1}, \mathrm{BC}_{1} \mathrm{~s}$ ) parents. Inheritance of resistance of the $S$. chmielewskii line was studied based on a quantitative genetics approach by a number of methods applied to the estimated virus accumulation ratings for plants of generations from the 'Moneymaker' $\times$ '821-13-1' cross. Testing of the implication of a major locus controlling the resistance was based upon the shape of the distribution of $F_{2}$ segregating population by calculation of coefficient of bimodality and departure from normal and uniform theoretical distributions as described by GarcíaCano et al. (16). Estimation of gene effects in the six-generation family was performed by the methods described by Mather and Jinks (37) using a self-made Excel sheet. The mid-parent value $m$ 
together with additive $(d)$ and dominance $(h)$ gene effects were considered. The adequacy of such $m d h$ additive-dominance model was tested by $A B C$ scaling tests. For those cases in which any of the three scaling tests was significant, the following models of gene effects including additive $\times$ additive $(i)$, additive $\times$ dominance $(j)$, and dominance $\times$ dominance $(l)$ terms of digenic epistatic interactions were then calculated: $m d h i, m d h j, m d h l, m d h i j$, and mahil. No degrees of freedom were left in the six-parameter mdhijl model and therefore it was not calculated. The best-fit model was chosen as that in which expected means deviated least from the observed means of the generations as indicated by a higher probability associated with the corresponding $\chi^{2}$ test.

Disease severity evaluation. The presence of the following leaf symptoms associated with ToCV infection was recorded: interveinal yellowing, red and brown necrotic patches, and upward curling. In controlled inoculations, the severity of each of these symptoms in test plants was rated according to the following visual scale: 0 , no visible symptoms; $1,20 \%$ of the plant exhibiting symptoms; $2,40 \%$ of the plant exhibiting symptoms; 3 , $60 \%$ of the plant exhibiting symptoms; $4,80 \%$ of the plant exhibiting symptoms, and 5, 100\% of the plant exhibiting symptoms. Also, intermediate scores were given to obtain accurate evaluations of ToCV symptom severity. In the initial germplasm screening, a 0 to 3 rating scale was used by merging scores 2 to 3 and 4 to 5 of the scale given above. Then, the symptom value assigned to each plant was the average of the three ratings. Disease progress curves were constructed based on symptom ratings, and the area under the symptom progress curve (AUSPC) was determined using the following formula: AUSPC $=\Sigma\left(\left(S_{i}+\right.\right.$ $\left.\left.S_{(i+1)}\right)\left(T_{(i+1)}-v T_{i}\right)\right) / 2$ with $S_{\mathrm{i}}=$ mean value of symptom scores at date $\mathrm{i}$, and $T_{i}=$ time (in days) at date $i$. AUSPC can be used as a descriptor of the disease progression (8).

Viral RNA detection. Presence of ToCV viral RNAs was analyzed in inoculated tomato plants either by tissue blot hybridization or by reverse transcription-polymerase chain reaction (RT-PCR). For tissue blot hybridization, freshly cross-sectioned leaf petioles or stems were squash-blotted on positively charged nylon membranes (Roche Diagnostics GmbH, Mannheim, Germany) and hybridized with a ToCV-specific probe as described (17). Although tissue-blotting is not a quantitative technique to determine virus accumulation, it was demonstrated to be useful in differentiating relative viral susceptibility among materials with different levels of resistance (44). Therefore, when needed, an indirect estimation of the virus infection level of analyzed plants was obtained from the intensity of the hybridization signal of tissue blots. For this, a hybridization scale from 0 (no hybridization signal) to 5 (maximum hybridization signal) was established based on a ToCV RNA2 transcript control. As loading control, a subsequent hybridization of tissue blot membranes was performed with a DIG-labeled DNA probe prepared by random priming to an $18 \mathrm{~S}$ ribosomal RNA gene clone (provided by E. R. Rodríguez-Cerezo, CNB-CSIC, Madrid, Spain). RT-PCR was performed using the forward MA380 (5'-GTGAGACCCCGA TGACAGAT-3') and reverse MA381 (5'-TACAGTTCCTTGCC CTCGTT-3') primers designed on the ToCV sequence (GenBank accession number AY444872) to amplify a 436-nt fragment of the coat protein gene. Total RNA was extracted using TRIzol reagents (Invitrogen, Carlsbad, CA) according to the manufacturer's instructions and RT-PCR was performed using Superscript OneStep RT-PCR with Platinum Taq Kit (Invitrogen Life Technologies) and the following conditions: $50^{\circ} \mathrm{C}$ for 30 minutes; initial denaturation at $94^{\circ} \mathrm{C}$ for $2 \mathrm{~min}$, followed by 35 cycles of $94^{\circ} \mathrm{C}$ for $15 \mathrm{~s}, 50^{\circ} \mathrm{C}$ for $30 \mathrm{~s}$, and $72^{\circ} \mathrm{C}$ for $30 \mathrm{~s}$, with a final extension at $72^{\circ} \mathrm{C}$ for $5 \mathrm{~min}$. Equal amounts of total RNA were included in each RT-PCR reaction. RT-PCR products were separated by electrophoresis in $1 \%$ agarose gels and stained with ethidium bromide to determine presence or absence of target DNA.
Examination of pollen performance in crosses. Pollen grain germination at the stigma and pollen tube growth in the style were inspected following the method described by Martin (34). Thus, styles (maintaining their stigmas) from hand-pollinated flowers were excised $72 \mathrm{~h}$ after pollination, when tomato pollen tubes have normally completed their path from the stigma to the ovary locule (43). Ovaries were not removed from the plants to check fruit setting and to allow seed production. Collected styles were then fixed in FAA (10\% formalin, 50\% ethanol, 5\% acetic acid) for $24 \mathrm{~h}$, soaked in $\mathrm{NaOH} 1 \mathrm{~N}$ for $6 \mathrm{~h}$, and stained overnight in a $0.1 \%$ (wt/vol) aniline blue, $\mathrm{K}_{3} \mathrm{PO}_{4} 0.3 \mathrm{~N}$ solution. Treated styles were placed on a microscope glass slide, gently pressed with cover glass and observed under an epifluorescence Leica DM LB2 microscope with an excitation wavelength of 340 to $380 \mathrm{~nm}$ and an emission wavelength of $425 \mathrm{~nm}$.

\section{RESULTS}

Germplasm screening for ToCV resistance. A total of 247 tomato cultivars and wild species accessions were tested for ToCV resistance under natural infection conditions. A complete list of tested materials (excluding commercial $F_{1}$ hybrids) and their performance is available as a supplementary table. In all field trials conducted, $100 \%$ ToCV infection occurred in the cv. Moneymaker and cv. Rambo $\mathrm{F}_{1}$ tomato plants used as susceptible controls. Also, all plants of two accessions, PE-44 of $S$. chmielewskii and T-55 of $S$. peruvianum, exhibited infections with severe yellowing symptoms and thereafter they were used as susceptible controls for those Solanum species. The symptoms of ToCV infection varied depending on the Solanum accession tested from mild yellowing or reddening to severe rolling and/or necrosis in affected leaves. In all cases, the disease progressed acropetally, with the upper part of plants appearing healthy. Symptoms characteristic of ToCV infection occurred in most plants of the wild species accessions tested. However, some accessions exhibited variability in symptom occurrence, especially one accession of $S$. chmielewskii (LA1028), one of S. chilense (LA2750), one of S. corneliomulleri (PI 126440), and one accession ('IAC CN RT') which comprised a phenotypically variable population originally obtained by IAC Campinas (Brazil) from an interspecific cross $S$. lycopersicum $\times S$. peruvianum LA0444. In general, plants of tomato genotypes exhibited prominent symptoms except for few cases in which moderate symptoms were observed, and the cv. Summer which exhibited some asymptomatic plants. A positive correlation existed between symptom expression and ToCV detection, although some nonsymptomatic plants tested positive. In the genotypes with variable responses, one or two rounds of self-pollination of asymptomatic plants or sib-crosses among asymptomatic plants were conducted combined with evaluation under natural infection to obtain progenies that were further characterized under controlled inoculation conditions.

Resistance of selected materials under controlled inoculation. The most promising progenies were evaluated in no-choice experiments under controlled conditions by mass inoculation of ToCV using B. tabaci as vector, and results are summarized in Table 1. In two different experiments, the $S$. chmielewskii line '821-13-1' derived by two rounds of self-pollination from LA1028, resulted in a low number of infected plants, with most of the inoculated plants being asymptomatic or exhibiting very mild yellowing symptoms only in older leaves at late dates (131 days) postinoculation (dpi). Interestingly, plants of the line '802-11-1', obtained after two rounds of self-pollination from 'IAC CN RT', exhibited no symptoms even at $131 \mathrm{dpi}$, and ToCV could not be detected except for one plant at late dates (90 dpi). In contrast, most inoculated plants of the population 'i721-5' (obtained from two cycles of sib-crossing in self-incompatible $S$. chilense accession LA2750), '708-4' (derived from one round of self-pollination 
of a 'Summer' plant), and PI 126440 developed severe ToCV symptoms and resulted in strong hybridization signals, similar to those observed for plants of the susceptible controls 'Moneymaker', PE-44, and T-55. In all cases, mock-inoculated plants were asymptomatic and no ToCV-infected plants were detected. The materials that exhibited consistent resistance, lines '821-13-1' and '802-11-1', were selected for further studies.

Characterization of ToCV resistance in '821-13-1' and '80211-1'. Plants of lines ' $821-13-1$ ' and ' $802-11-1$ ' were further inoculated individually with ToCV using $B$. tabaci and clip-on cages. In three replicated experiments, similar results were obtained (as shown for one replicate in Fig. 1). Thus, in plants of '821-13-1' only very mild symptoms were observed, and just in the oldest leaves at later dates (after $50 \mathrm{dpi}$, Fig. 1A). In contrast, in the susceptible controls S. chmielewskii PE-44 and S. lycopersicum 'Moneymaker', ToCV symptoms were observed in plants even at early dates (after $30 \mathrm{dpi}$, Fig. 1A). Notably, disease progress resulted in large differences between '821-13-1' and the susceptible controls in their AUSPCs $\left(\right.$ AUSPC $_{821-13-1}=8.3$; $\left.\mathrm{AUSPC}_{\mathrm{PE}-44}=189.5 ; \mathrm{AUSPC}_{\text {Moneymaker }}=129.3\right)$. Moreover, analysis of virus presence in '821-13-1' plants indicated that ToCV was detected only in some plants at late dates (e.g., plants 5, 6, and 7 at 72 dpi, Fig. 1B); in contrast, all inoculated plants of the susceptible controls 'Moneymaker' and PE-44 exhibited clear hybridization signals of infection from early dates after inoculation in most of the plant levels analyzed (Fig. 1B). A remarkable resistance to ToCV was observed in plants of the line '802-11-1' that exhibited no symptoms (Fig. 1C) and complete absence of virus infection (by hybridization and RT-PCR) even at $75 \mathrm{dpi}$, in contrast to plants of the susceptible control 'Moneymaker' (Fig. 1D). Consequently, disease progress curves greatly differed between '802-11-1' and 'Moneymaker' (Fig. 1C).

Resistance of plants of '802-11-1' and '821-13-1' was further evaluated under continuous ToCV inoculation by means of graft inoculation experiments. Top-grafting of ' $802-11-1$ ' healthy scions onto ToCV-infected 'Moneymaker' rootstocks indicated that even under these conditions, a strong restriction to virus accumulation was observed in these plants in two replicated experiments (five plants per experiment). Thus, ToCV was detected in noninoculated young leaves only at late dates ( $45 \mathrm{dpi}$ ) postinoculation in a single plant of ' $802-11-1$ ' by molecular hybridization and in two plants by RT-PCR, while ToCV was readily detected in all 'Moneymaker' control plants after 15 dpi by hybridization and RT-PCR (not shown). Interestingly, double-graft experiments on
ToCV-infected 'Moneymaker' rootstock plants suggested that most '802-11-1' plants conferred a restriction to long-distance invasion of ToCV. Thus, as summarized in Table 2, when '802-111 ' intergrafts were used, ToCV was detected by hybridization in few top scions and intergrafts but only at late dates (70 dpi) (Fig. 2A). RT-PCR analysis suggested that traces of virus seemed to be present at late dates (70 dpi) in hybridization-negative '802-11-1' intergrafts and 'Moneymaker' top scions (Table 2; Fig. 2B) suggesting that ToCV circulation is restricted but not totally impeded in '802-11-1'. No such restriction was observed when 'Moneymaker' intergrafts were used (Table 2; Fig. 2).

When '821-13-1' was graft-inoculated onto ToCV-infected 'Moneymaker' plants, ToCV readily accumulated in the scions from early dates, following the same pattern observed in control plants using 'Moneymaker' as scion (not shown). This might suggest that the resistance in this case could depend on virus pressure. Therefore, a natural high virus pressure at early growth stages was simulated on ' $821-13-1$ ' plants by challenging them to continuous mass inoculation with ToCV during 15 days using about 400 viruliferous whiteflies per plant. Under these conditions, ToCV was readily detected in every ' $821-13-1$ ' plant from early dates after inoculation by tissue blot hybridization similarly to that observed for the susceptible controls 'Moneymaker' and PE-44 (Fig. 3A). However, even under these conditions, disease development strongly differed between '821-13-1' and the susceptible control plants. Thus, only mild yellowing symptoms in the oldest leaves at late dates (after $50 \mathrm{dpi}$ ) were observed in '821-13-1' plants, in contrast to the severe ToCV infection symptoms observed from early dates after inoculation in plants of the susceptible controls (Fig. 3B). Therefore, this resistance was effective even under high virus pressure.

Altogether, the above results indicated that both '821-13-1' and '802-11-1' exhibited resistance to ToCV, although they were not immune to infection.

Inheritance of the ToCV-resistance. Attempts to cross the line '802-11-1' (S. lycopersicum $\times$ S. peruvianum genetic background) with the susceptible cv. Moneymaker failed. The primary problem was the decreased pollen viability observed in inbred '802-11-1' that was obtained after two selfing steps. Then, as shown in Figure 4, in contrast to that observed for the control 'Moneymaker' self-pollinations (Fig. 4A and B), in 'Moneymaker' $\times$ '802-11-1' crosses, few '802-11-1' pollen grains germinated in the stigma of 'Moneymaker' (Fig. 4C), and no pollen tubes of '80211-1' reached the stylar end (Fig. 4D). In the latter crosses, it was

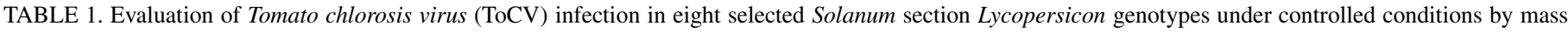
inoculation $^{\mathrm{w}}$

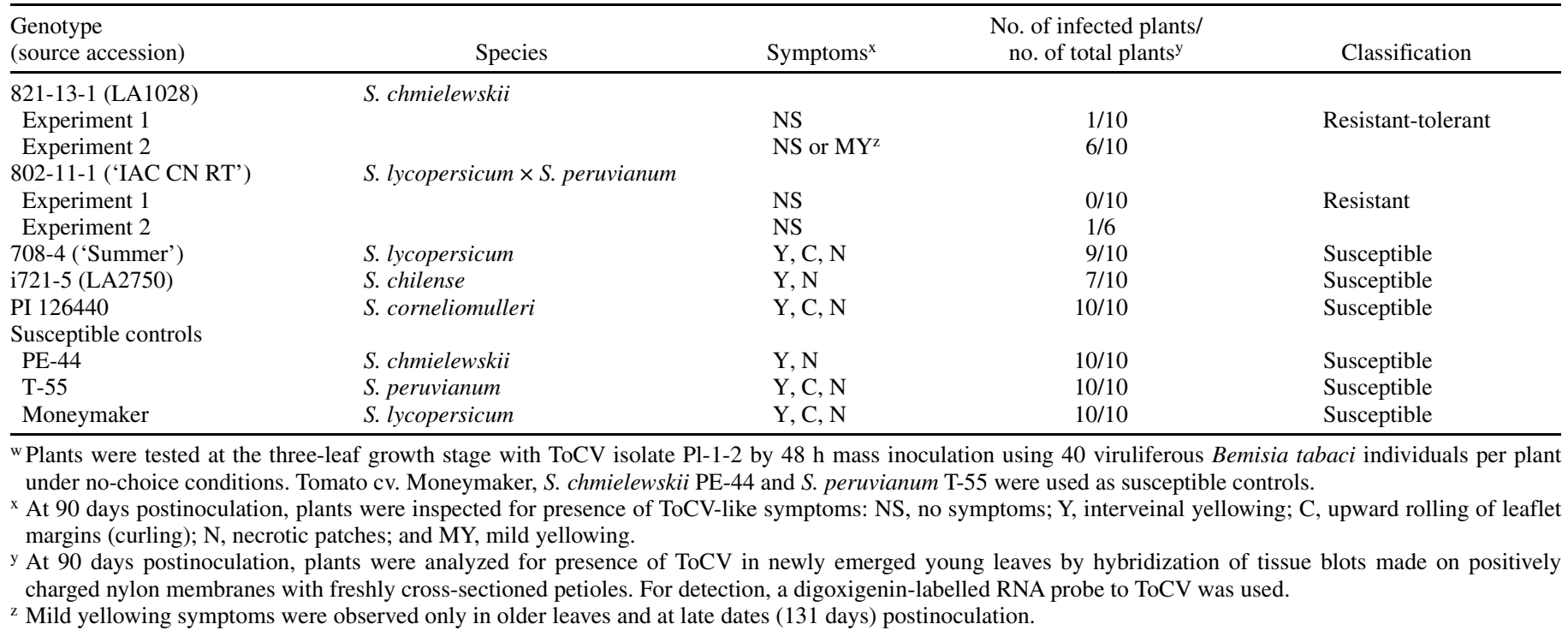


also observed that the few pollen tubes that grew toward the 'Moneymaker' ovary arrested growth before reaching the stylar end (Fig. 4D), thus leading to seedless fruits. Moreover, in reciprocal '802-11-1' $\times$ 'Moneymaker' crosses, 'Moneymaker' pollen grains germinated (Fig. 4E) and pollen tubes reached the '802-11-1' ovary (Fig. 4F) but pollinated flowers dropped and no fruit were set. Therefore, the observed crossing barrier impeded the study of inheritance of ToCV resistance in '802-11-1'.
In contrast, the family of generations of the 'Moneymaker' $x$ '821-13-1' cross was easily obtained. Then, the six generations of that family were inoculated with ToCV following the individual plant inoculation method. As attempts to study these generations under greenhouse conditions failed because unwanted begomovirus (family Geminiviridae) infections with Tomato yellow leaf curl virus that masked ToCV infections, the study was conducted in growth chamber that allowed us to perform replicates under
A

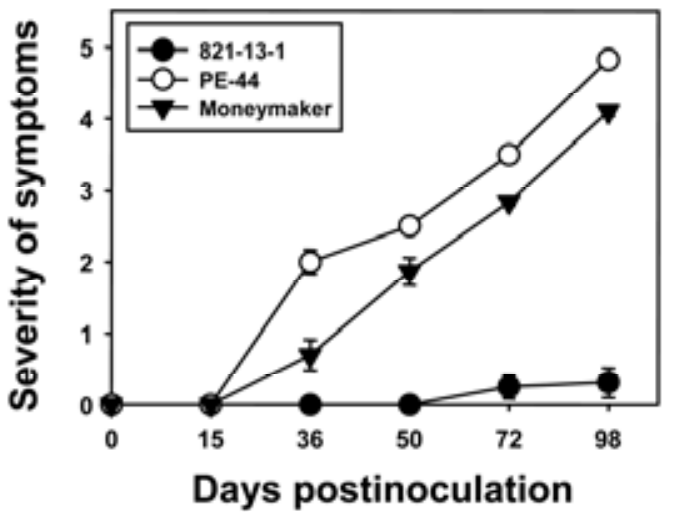

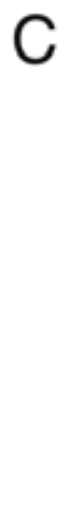

$\mathrm{D}$
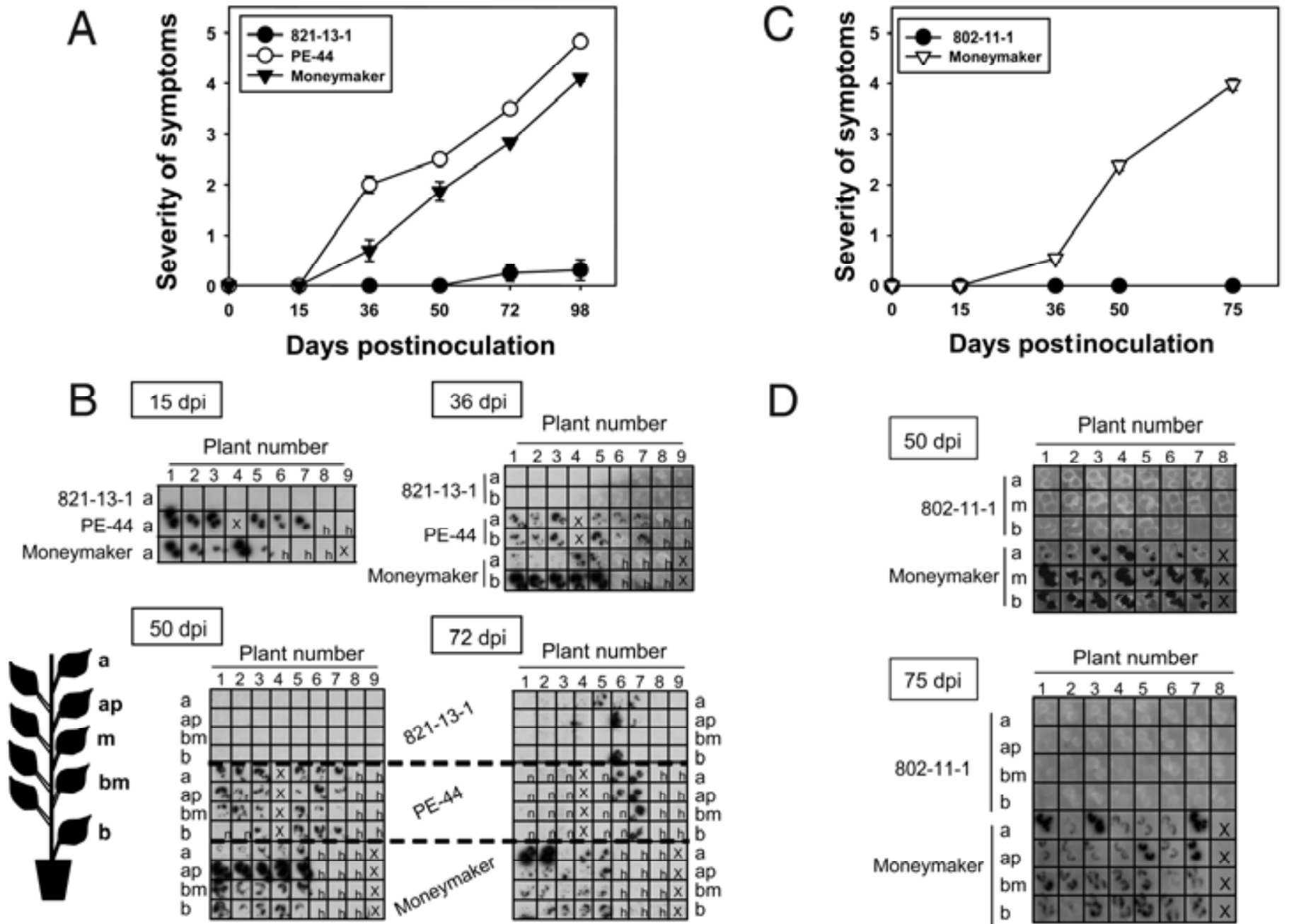
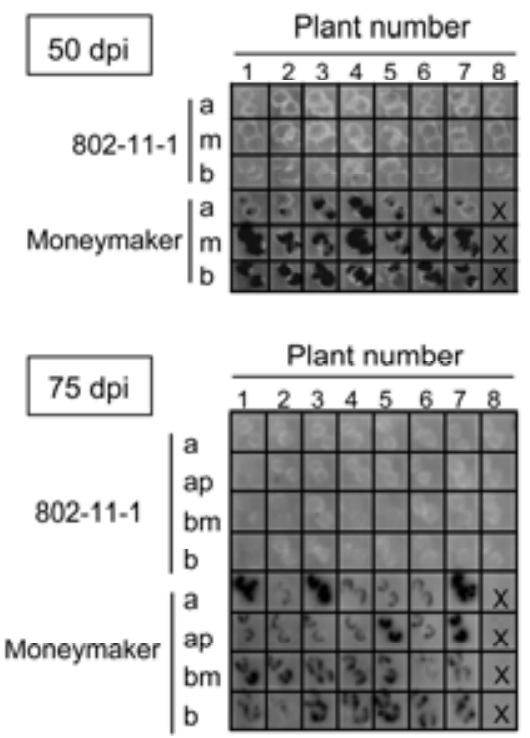

Fig. 1. Experimental inoculation of Tomato chlorosis virus (ToCV) to plants of lines '821-13-1' and '802-11-1' using Bemisia tabaci following individual plant inoculation. Plants of tomato cv. Moneymaker and Solanum chmielewskii PE-44 were included as susceptible controls. A and C, Evolution of symptom severity (0, no symptoms; 5, maximum ToCV symptom severity); results shown are mean \pm standard error. B and D, Detection of ToCV by hybridization of squash blots of leaf petiole cross sections (two squash blots per leaf petiole) performed on positively charged nylon membranes at several days postinoculation (dpi) and at several leaf positions (a, apical; ap, apical medium; m, medium; bm, basal medium; and b, basal) schematically represented on the left of the figure. $h$ indicates squash blot from a healthy plant; $\mathrm{n}$, squash blot not performed because of presence of a generalized necrosis in the leaf; and X, no squash blot present.

TABLE 2. Detection of Tomato chlorosis virus (ToCV) by molecular hybridization and reverse transcription-polymerase chain reaction (RT-PCR) at several days postinoculation (dpi) in top scions and intergrafts in double-grafts performed on ToCV-infected tomato cv. Moneymaker plants using healthy '802-11-1' or 'Moneymaker' as intergraft and healthy 'Moneymaker' as top scion ${ }^{\mathrm{x}}$

\begin{tabular}{|c|c|c|c|c|c|c|c|c|c|c|c|}
\hline \multirow[b]{2}{*}{$\begin{array}{l}\text { Top scion/ } \\
\text { intergraft/rootstock }\end{array}$} & \multirow[b]{2}{*}{$\begin{array}{c}\text { Tissue } \\
\text { analyzed }\end{array}$} & \multicolumn{2}{|c|}{$17 \mathrm{dpi}^{\mathrm{z}}$} & \multicolumn{2}{|c|}{$30 \mathrm{dpi}$} & \multicolumn{2}{|c|}{45 dpi } & \multicolumn{2}{|c|}{$57 \mathrm{dpi}$} & \multicolumn{2}{|c|}{70 dpi } \\
\hline & & $\begin{array}{l}\text { Hybridi- } \\
\text { zation }\end{array}$ & RT-PCR & $\begin{array}{l}\text { Hybridi- } \\
\text { zation }\end{array}$ & RT-PCR & $\begin{array}{l}\text { Hybridi- } \\
\text { zation }\end{array}$ & RT-PCR & $\begin{array}{l}\text { Hybridi- } \\
\text { zation }\end{array}$ & RT-PCR & $\begin{array}{l}\text { Hybridi- } \\
\text { zation }\end{array}$ & RT-PCR \\
\hline MM/802-11-1/MMi & Top scion & $0 / 5$ & $0 / 5$ & $0 / 5$ & $0 / 5$ & $0 / 5$ & $0 / 5$ & $0 / 5$ & $0 / 5$ & $2 / 5$ & $4 / 5$ \\
\hline MM/MM/MMi & Top scion & $5 / 5$ & $5 / 5$ & $5 / 5$ & $5 / 5$ & $5 / 5$ & $5 / 5$ & $5 / 5$ & $5 / 5$ & $5 / 5$ & $5 / 5$ \\
\hline & Intergraft & $5 / 5$ & $5 / 5$ & $5 / 5$ & $5 / 5$ & $5 / 5$ & $5 / 5$ & $5 / 5$ & $5 / 5$ & $5 / 5$ & $5 / 5$ \\
\hline
\end{tabular}

${ }^{x}$ At 17 to $57 \mathrm{dpi}$, a nondestructive analysis was conducted, analyzing tissue of lateral shoots of intergrafts, and of the youngest leaves of top scions. At 70 dpi, a destructive analysis was conducted, analyzing stem and lateral shoot tissues of intergrafts and stem and youngest leaves of top scions. A complete correlation was found between results for stem and lateral shoots at $70 \mathrm{dpi}$.

${ }^{y} \mathrm{MMi}, \mathrm{ToCV}$-infected tomato plants of the susceptible cv. Moneymaker; MM, healthy 'Moneymaker' plant.

${ }^{\mathrm{z}}$ dpi, days after the second grafting. 
constant conditions and free of disturbing heterologous infections. In these conditions, growth to symptom development was not feasible owing to space limitations because clear ToCV symptom only appear 50 to 60 days after inoculation. However, a good descriptor of the resistance observed in '821-13-1' was found based on the intensity of the ToCV hybridization signal observed in tissue blots from young leaf petioles of test plants at early dates after inoculation. Therefore, this descriptor was used to study the genetic control of the resistance to virus infection estimated from the hybridization signal level. Thus, at 15 dpi most '821-13-1' plants exhibited absence or very light hybridization signals whereas most of the 'Moneymaker' plants exhibited strong hybridization signals for similar nucleic acid loads, just like in the initial experiment done using individual plant inoculations (Fig. 1B). However, $F_{1}$ plants exhibited a variable response that overlapped with parental values and thus no clear phenotypes could be established to perform a segregation study in a Mendelian approach. Therefore, at $15 \mathrm{dpi}$ each plant of the generations was assigned a hybridization signal value (scale 0 to 5) and inheritance of resistance was analyzed quantitatively. Quantitative responses of the generations with hybridization signals are shown in Figure 5. We observed the partial overlapping of parents and the complete overlapping of $F_{1}$ with both parental lines. The backcrosses exhibited the expected response, i.e., a wide segregation with the more frequent phenotypes being like those of the respective recurrent parent. Bimodality of $\mathrm{F}_{2}$ frequency distribution was apparent (Fig. 5) which was statistically supported by the calculated value of the coefficient of bimodality $(b=0.550)$ and by deviation of uniform and normal distributions $(P<0.001)$, which provide evidence of a genetic control of the resistance to ToCV infection by a major locus. Based on the means, variances, and population sizes of the generations, scaling tests and quantitative gene effects were estimated and the best-fit model is given in Table 3. Significant deviation from zero of scaling tests $A, B$, and $C$ indicated that additive-dominance model was not adequate. Therefore, epistatic interactions were tested. The bestfit model suggested significant additive, dominance, and additive $x$ dominance interaction effects (Table 3 ). The greatest effects were additive, but significant positive dominance and additive $\times$ dominance effects revealed tendency to more intense virus hybridization in heterozygous genotypes. The estimated mean degree of dominance was 0.32 that fits with partial dominance. Therefore, the quantitative analyses suggested that the resistance to ToCV infection in '821-13-1' could be oligogenic, governed by a major locus with partial dominance toward higher susceptibility modified by epistatic additive $\times$ dominance interactions with other minor genes.

\section{DISCUSSION}

Here we have found and characterized for the first time sources for resistance to ToCV that eventually could serve to breed commercial tomato cultivars. During the screenings in search for ToCV resistance, a number of accessions were identified which exhibited an interesting level of resistance under the choice field conditions, however in some cases this was not maintained in no-
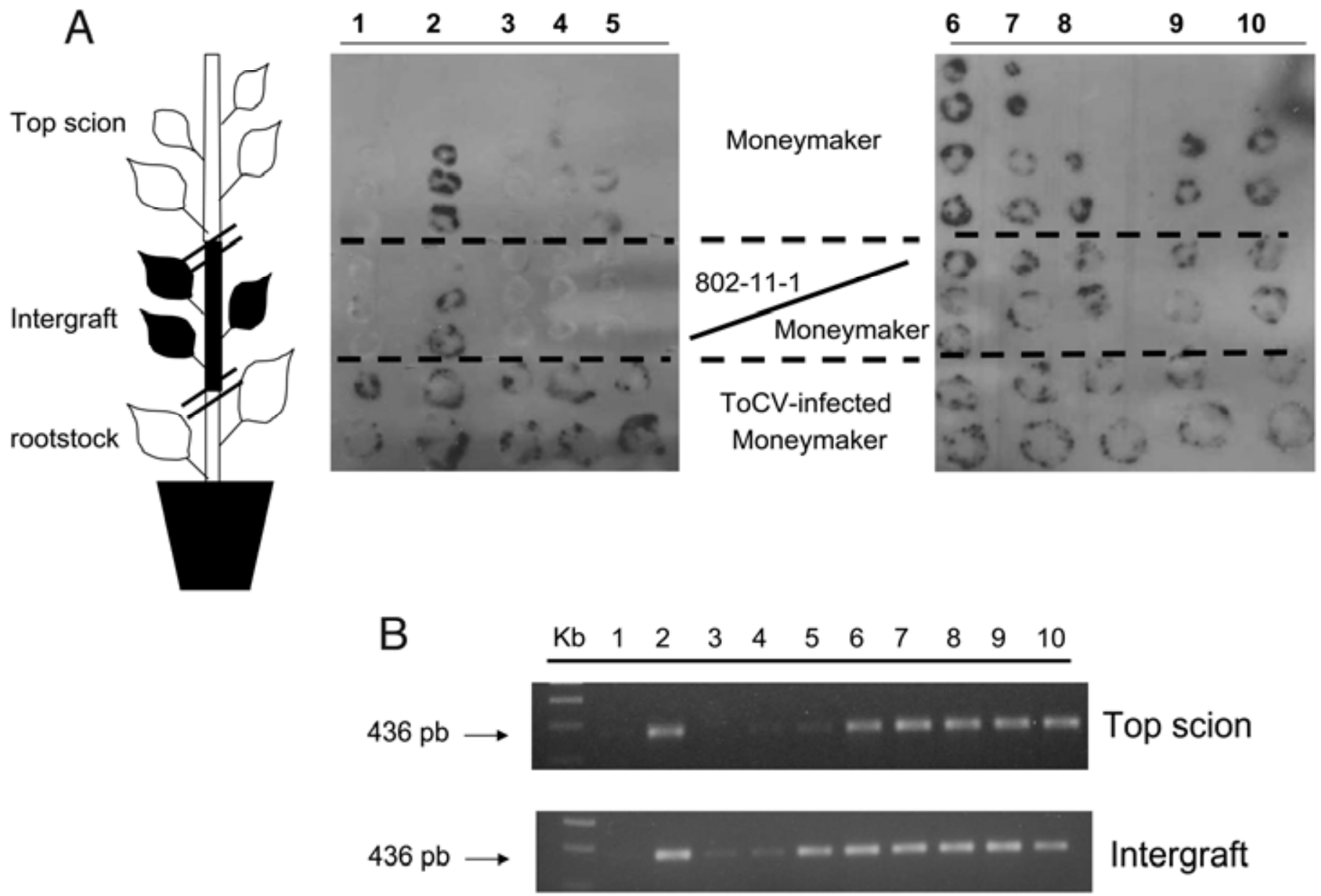

Fig. 2. Double-graft assays using Tomato chlorosis virus (ToCV)-infected 'Moneymaker' rootstocks and healthy 'Moneymaker' top-scions with either healthy '802-11-1' (plants 1 to 5) or 'Moneymaker' (plants 6 to 10) intergrafts. Plants were analyzed at 70 days after the second grafting either A, by hybridization of squash blots of stem cross sections performed on positively charged nylon membranes at several plant levels or $\mathbf{B}$, by reverse transcription-polymerase chain reaction in RNA extracts obtained from stem tissues of the 'Moneymaker' top-scion or intergraft. 
choice conditions under controlled inoculations. This was the case of 'i721-5' (derived from $S$ chilense LA2750), '708-4' (derived from S. lycopersicum cv. Summer), and PI 126440 (S. corneliomulleri). In these cases, although field resistance was observed, efficient infections were obtained under controlled conditions constraining viruliferous whiteflies on test plants. Therefore, the differences observed between field and controlled inoculations might result of differences in the inoculum pressure (25) but also might reflect some insect resistance in these genotypes $(27,41)$ that interferes with plant selection by whiteflies $(10,51)$. It is interesting to note that resistance associated to a lower propensity to virus infection by a vector might constitute a first barrier in an integrated disease control approach $(20-22,60)$. Therefore, the resistance observed in 'i721-5', '708-4', and PI 126440 merits further study because it might be a useful complement to control ToCV epidemics in tomato. However, in this work we concentrated on two lines, '802-11-1' and '821-13-1', that exhibited significant resistance under natural infection conditions and after challenging with ToCV under controlled inoculations. Both lines were derived by two self-pollinations from ToCV asymptomatic plants of accessions with a variable response under natural infection conditions and were candidates as major sources of resistance. Of special interest was the resistance detected in the tomato line '802-11-1' derived from the accession 'IAC CN RT'. We demonstrated that even if plants of '802-11-1' were not immune to infection of ToCV, no symptoms were observed and virus could hardly be detected in the few infected plants. Moreover, even after challenging ToCV by graft-inoculation, most of the '802-11-1' plants exhibited a stable resistance, suggesting a resistance to systemic virus spread. This was substantiated by triple graft experiments which demonstrated that the intergrafts of '80211-1' restricted ToCV spread from the infected susceptible rootstock to the healthy susceptible top scion. Therefore, following Cooper and Jones (11), resistance to the virus and tolerance to the disease was observed in '802-11-1'. It should be further studied to determine if the virus resistance operates at early infection phases (replication and/or cell-to-cell movement), or at long-distance movement level, or if it results from the activation of a defense response in plants like gene silencing $(18,33,42,59)$. These studies would be better conducted after the introgression of the resistance into a $S$. lycopersicum background. Unfortunately, crossing barriers with the susceptible tomato cv. Moneymaker were found that frustrated the cross. Firstly, pollen fertility of inbred line '802-11-1' was low, what could be explained by accumulation of loci in homozygosis. In fact, it has been reported that additive epistatic interactions in hybrids of tomato with the wild species $S$. habrochaites explain the reduced proportion of viable pollen produced (38), hypothesizing that certain homozygous loci from the wild species in S. lycopersicum genetic background might be behind hybrid infertility. Secondly, we also observed that in crosses using as staminate parents less inbred materials of this $S$. lycopersicum $\times S$. peruvianum genetic background, such as 'IAC CN RT' itself or a plant coming from one selfing step, pollen tubes grew normally into the ovary (not shown) but all the ob-
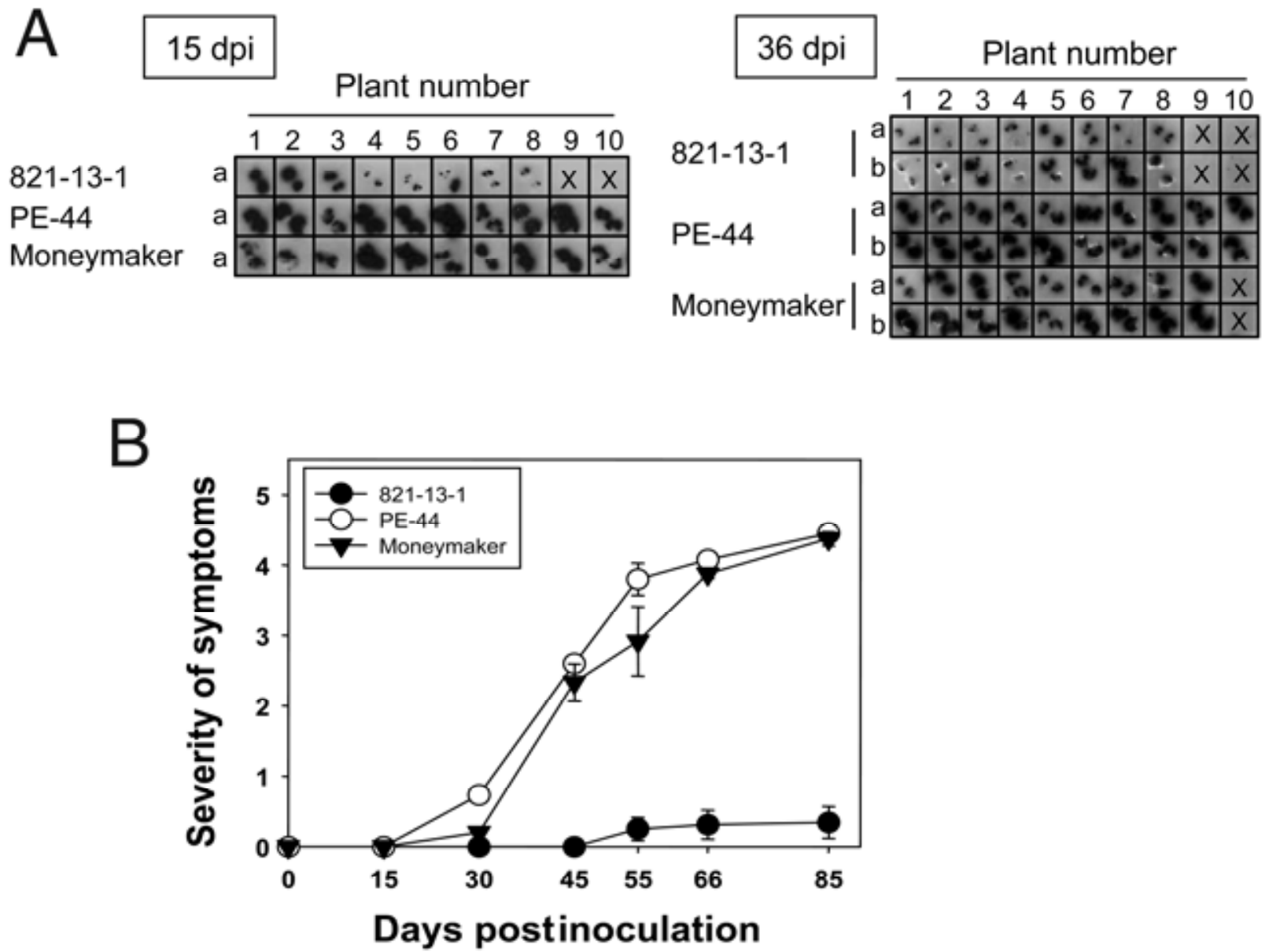

Fig. 3. Detection of Tomato chlorosis virus (ToCV) in Solanum chmielewskii '821-13-1' and susceptible control tomato 'Moneymaker' and S. chmielewskii PE-44 plants after challenging plants with extremely high ToCV pressure by continuous mass inoculation using Bemisia tabaci during 15 days with a total of 400 viruliferous whiteflies per plant. A, Autoradiograph for ToCV hybridization results of positively charged nylon membranes with squash blots of leaf petiole cross sections (two squash blots per leaf petiole) performed at 15 and 36 days postinoculation (dpi) and at several leaf positions (a, apical and b, basal), with plant number indicated at the top of the figure. $\mathrm{X}$ indicates no sample present. B, Evolution of ToCV-like symptoms ( 0 , no symptoms; 5 , maximum ToCV symptom severity) observed in inoculated plants. Results are mean \pm standard error for 10 inoculated plants. 
tained fruits were seedless. Moreover, in this latter case no fruit set was achieved when these materials acted as the pistillate parent in the crosses. Therefore, these results strongly suggested that the $S$. peruvianum genome still contained in 'IAC CN RT' and derived materials causes unilateral incompatibility (40). Aan embryo rescue program (40) is currently being conducted to exploit the ToCV resistance found.

The line '821-13-1' derived from the accession LA1028 of $S$. chmielewskii also exhibited significant resistance to ToCV and tolerance to disease symptoms development (11) although some plants could be infected. Discovery of this resistance was surprising because to our knowledge this would only be the second report of virus resistance in this host species. Historically, $S$. chmielewskii has only been exploited for tomato breeding as donor of fruit quality characters (46), and except for a recent report of resistance to the potyvirus (family Potyviridae) Potato virus $Y$ (9), only a partial resistance to a fungal disease, powdery mildew, has been found in this wild tomato species (28). In contrast to '802-11-1', ToCV infection symptoms could be observed in '821-13-1'-infected plants although very mild, at late dates (after $50 \mathrm{dpi}$ ) postinoculation, and restricted to the oldest leaves. Interestingly, this resistance to disease symptom expression was stable even after challenging plants with a very high virus infection pressure, thus suggesting that '821-13-1' can be a significant source for resistance to ToCV. Nevertheless, it should be highlighted that ToCV could be detected systemically infecting plants of '821-13-1' but a significant restriction to virus accumulation was observed under low to medium infection pressures. Thus, even if ToCV infection could occur in some plants, the restriction to systemic virus accumulation might help to limit secondary virus spread owing to limited virus availability for vectors, as shown for other plant virus systems (24). No restriction to virus infection was observed when plants were graftinoculated, therefore suggesting that the resistance might operate in phases previous to the virus entry into phloem sieve elements, a major barrier to virus infection (4). Alternatively, plant defenses might be overwhelmed by a continuous supply of virus as observed in other cases $(7,56)$. The latter seems to be supported by the similar lack of restriction to virus accumulation observed when '821-13-1' plants were challenged under continuous and high viruliferous whiteflies pressure. Then, as for '802-11-1', further research should be conducted to fully understand the mechanisms associated with this resistance after its introgression into an S. lycopersicum background.

The genetic control of ' $821-13-1$ ' resistance to ToCV infection was also studied in this work. The intermediate susceptibility observed in plants of the $F_{1}$ between '821-13-1' and the susceptible cv. Moneymaker suggested an intermediate resistance which normally is associated with the predominance of additive effects. In fact, the quantitative genetic analyses suggested an oligogenic resistance to ToCV in '821-13-1', governed by a major locus with partial dominance and modified by epistatic additive $\times$ dominance
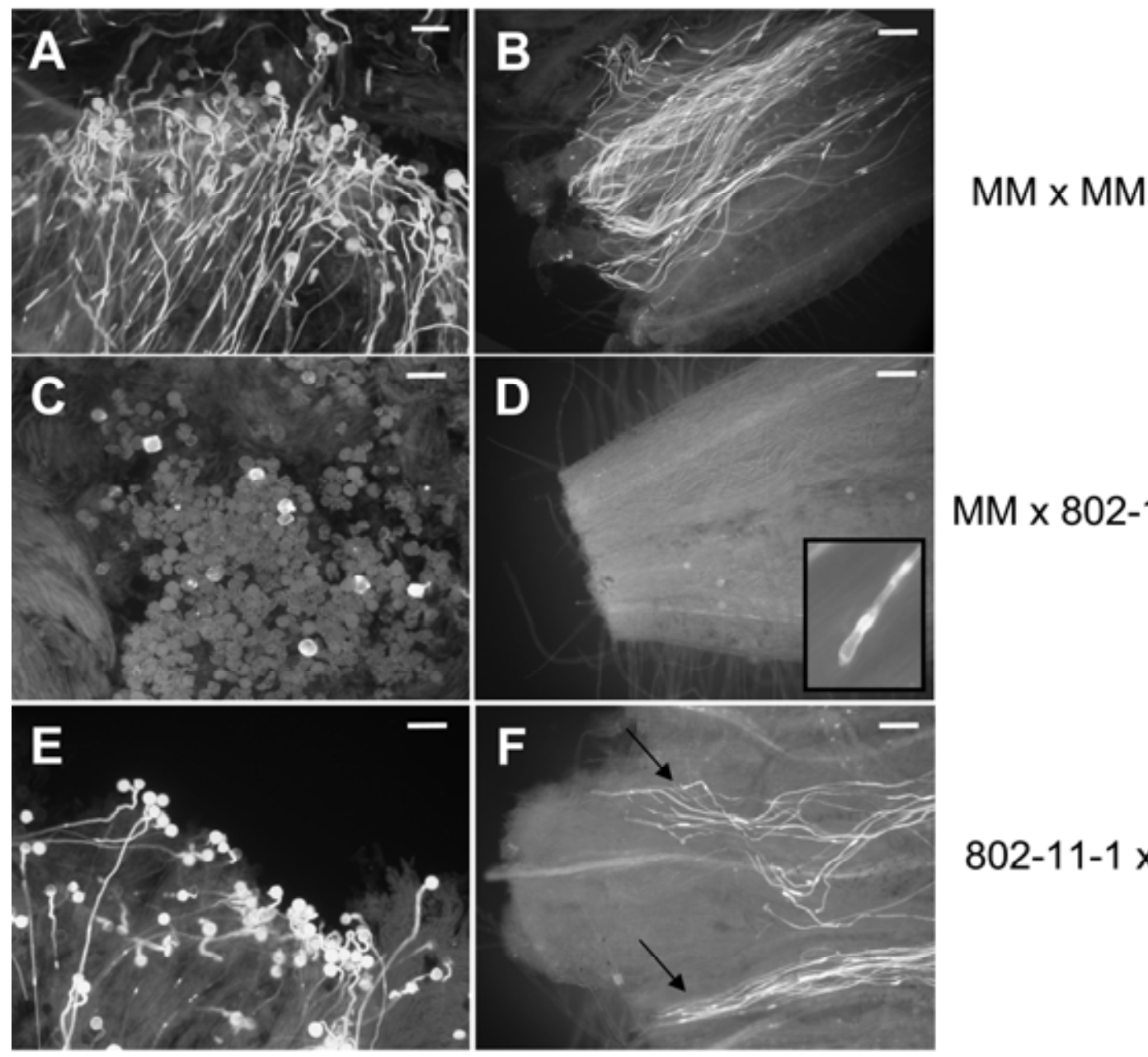

$M M \times 802-11-1$

$802-11-1 \times \mathrm{MM}$

Fig. 4. Micrographs of pistils after crosses in and between 'Moneymaker' (MM) and line '802-11-1' showing pollen grain germination and pollen tube growth in stigmas and styles by staining with aniline blue and observation by fluorescence microscopy. A, Normal germination and initial tube growth of 'Moneymaker' pollen on 'Moneymaker' stigmas; and B, many 'Moneymaker' pollen tubes growing through a 'Moneymaker' style. C, Scarce germination of '802-11-1' pollen on a 'Moneymaker' stigma, and D, example of a 'Moneymaker' style-end in which no '802-11-1' pollen tube reached the ovary, showing the detail of a pollen tube with arrested growth in the style. E, Germination of 'Moneymaker' pollen on a '802-11-1' stigma; and F, arrows indicate 'Moneymaker' pollen tubes reaching the '802-11-1' style-end. Bars indicate $200 \mu \mathrm{m}$ in all panels. 


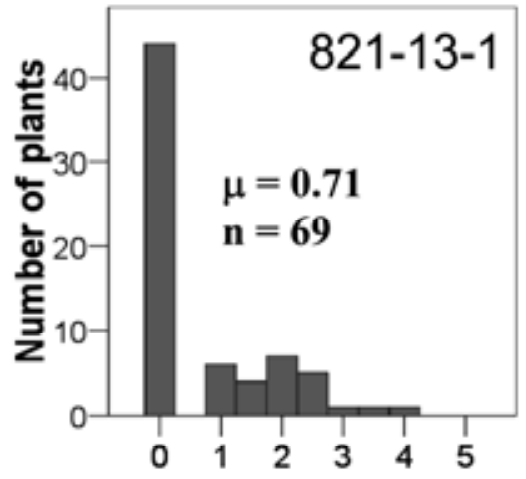

Hybridization signal

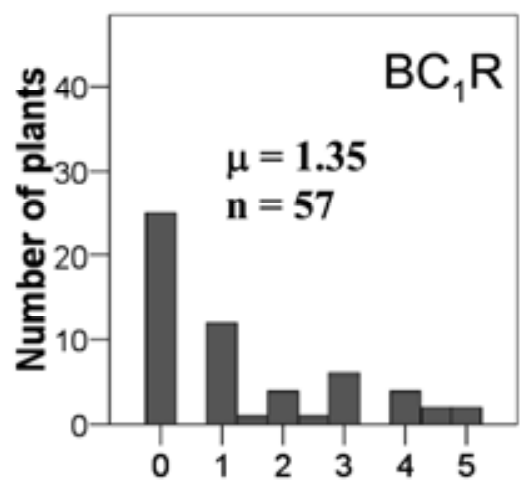

Hybridization signal

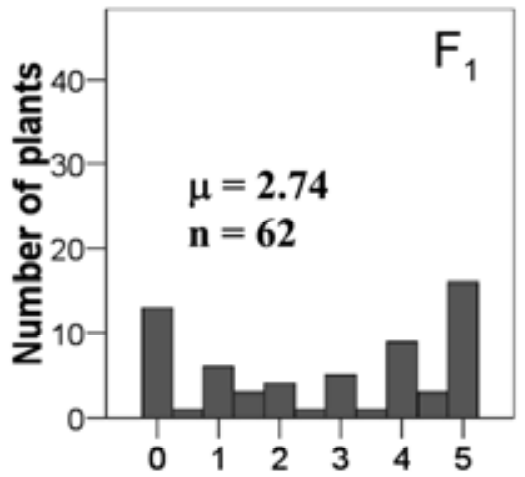

Hybridization signal

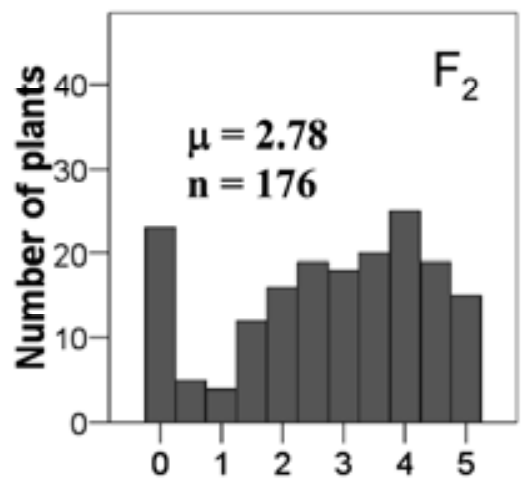

Hybridization signal

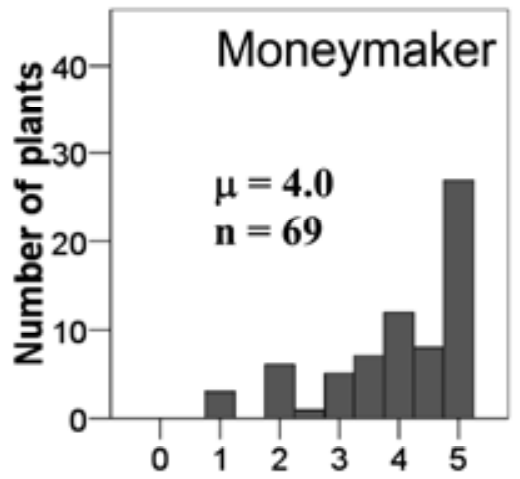

Hybridization signal

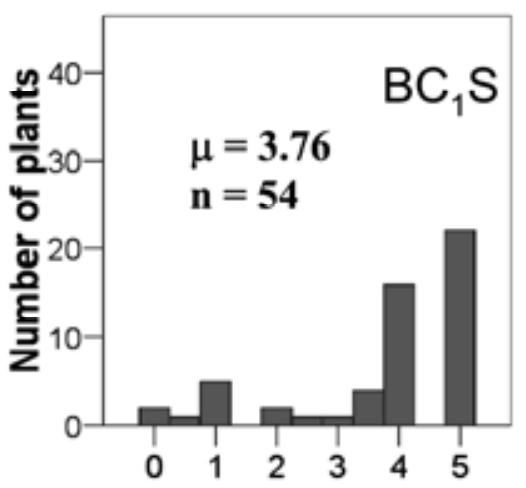

Hybridization signal

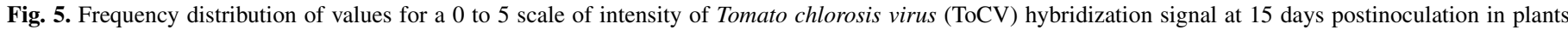

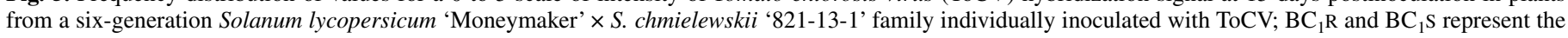

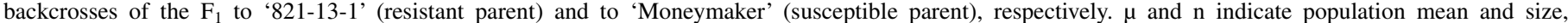
respectively.

TABLE 3. Estimates of gene effects \pm standard error (SE), scaling tests $( \pm$ $\mathrm{SE}$ ), chi-square test of best-fit model adjustment, broad-sense heritability, and mean degree of dominance for estimated virus accumulation based on hybridization signal scale ( 0 to 5 ) values after individual inoculation with Tomato chlorosis virus of plants from a six-generation Solanum lycopersicum 'Moneymaker' $\times$ S. chmielewskii '821-13-1' family

\begin{tabular}{lc}
\hline Genetic parameters $^{\mathrm{z}}$ & Estimated virus accumulation \\
\hline$m$ & $2.38 \pm 0.09$ \\
$d$ & $1.65 \pm 0.09$ \\
$h$ & $0.52 \pm 0.21$ \\
$i$ & $\ldots$ \\
$j$ & $1.51 \pm 0.62$ \\
$l$ & $\ldots$ \\
$A$ & $0.78 \pm 0.50$ \\
$B$ & $-0.74 \pm 0.50$ \\
$C$ & $0.92 \pm 0.71$ \\
$\chi^{2}$ & $2.18(2 \mathrm{df})$ \\
$P$ & 0.3364 \\
MDD & 0.32 \\
\hline
\end{tabular}

${ }^{\mathrm{z}} m$, mid-parent value; $d$, additive effects; $h$, dominance effects; $i$, additive $\times$ additive effects; $j$, additive $\times$ dominance effects; $l$, dominance $\times$ dominance effects; $A, B$, and $C$, scaling tests; and MDD, mean degree of dominance $(=h / d)$.

interactions with other minor genes. Therefore, the practical use of this resistance trait in breeding programs is possible, but requires that the resulting resistant cultivars be homozygous for the gene or genes associated with the resistance, especially because the character is mostly additive. Correlation between ToCV infection level and severity of disease symptoms at late dates needs to be further studied to better understand this resistance.
In conclusion, we have identified and characterized for the first time two sources of resistance to ToCV that impair virus accumulation and disease symptom expression: the line '802-11-1' with a strong resistance to the virus and absence of disease symptoms, and the line '821-13-1' with partial resistance to the virus and tolerance to the disease. Both resistances are relevant because no other sources of resistance to ToCV are available and could potentially be used to breed commercial tomatoes resistant to this emerging virus.

\section{ACKNOWLEDGMENTS}

This work was supported in part by grants AGL2004-06959-C0401/AGR and AGL2007-66062-C02-01/AGR of Ministerio de Educación y Ciencia (MEC), Spain (cofinanced by FEDER). E. García-Cano completed this research as part of her Ph.D. degree. We thank J. W. Scott for helpful discussion and critical reading of the manuscript and M. V. Martín and R. Escobar for technical assistance.

\section{LITERATURE CITED}

1. Abou-Jawdah, Y., El Mohtar, C., Atamian, H., and Sobh, H. 2006. First report of Tomato chlorosis virus in Lebanon. Plant Dis. 90:378.

2. Accotto, G. P., Vaira, A. M., and Vecchiati, M. 2001. First report of Tomato chlorosis virus in Italy. Plant Dis. 85:1208.

3. Barbosa, J. C., Teixeira, A. P. M., Moreira, A. G., Camargo, L. E. A., Filho, A. B., Kitajima, E. W., and Rezende, J. A. M. 2008. First report of Tomato chlorosis virus infecting tomato crops in Brazil. Plant Dis. 92:1709.

4. Bruening, G. 2006. Resistance to Infection. Pages 211-240 in: Natural Resistance Mechanisms of Plants to Viruses. G. Loebenstein and J. P. Carr, eds. Springer, Dordrecht, The Netherlands.

5. Cahill, M., Gorman, K., Day, S., Denholm, I., Elbert, A., and Nauen, R. 
1996. Baseline determination and detection of resistance to imidacloprid in Bemisia tabaci (Homoptera: Aleyrodidae). Bull. Entomol. Res. 86:343349.

6. Cahill, M., Jarvis, W., Gorman, K., and Denholm, I. 1996. Resolution of baseline responses and documentation of resistance to buprofezin in Bemisia tabaci (Homoptera: Aleyrodidae). Bull. Entomol. Res. 86:117122.

7. Canto, T., and Palukaitis, P. 2001. A cucumber mosaic virus (CMV) RNA 1 transgene mediates suppression of the homologous viral RNA 1 constitutively and prevents CMV entry into the phloem. J. Virol. 75:91149120.

8. Caranta, C., Pflieger, S., Lefebvre, V., Daubeze, A. M., Thabuis, A., and Palloix, A. 2002. QTLs involved in the restriction of cucumber mosaic virus (CMV) long-distance movement in pepper. Theor. Appl. Genet. 104:586-591.

9. Çelebi Toprak, F., Barutçu, E., Frary, A., and Doganlar, S. 2009. Identification of Potato $\mathrm{Y}$ potyvirus (PVY-0) resistance in wild and cultivated tomatoes. Turk. J. Agric. For. 33:11-17.

10. Chu, C. C., Henneberry, T. J., and Cohen, A. C. 1995. Bemisia argentifolii (Homoptera, Aleyrodidae) host preference and factors affecting oviposition and feeding site preference. Environ. Entomol. 24:354-360.

11. Cooper, J. I., and Jones, A. T. 1983. Responses of plants to viruses: Proposal for the use of terms. Phytopathology 73:127-128.

12. Dalmon, A., Fabre, F., Guilbaud, L., Lecoq, H., and Jaquemond, M. 2009. Comparative whitefly transmission of Tomato chlorosis virus and Tomato infectious chlorosis virus from single or mixed infections. Plant Pathol. 58:221-227.

13. Delatte, H., Naze, F., Cottineau, J. S., Lefeuvre, P., Hostachy, B., Reynaud, B., and Lett, J. M. 2006. Occurrence of Tomato chlorosis virus on tomato in Reunion Island. Plant Pathol. 55:289.

14. Dovas, C. I., Katis, N. I., and Avgelis, A. D. 2002. Multiplex detection of criniviruses associated with epidemics of a yellowing disease of tomato in Greece. Plant Dis. 86:1345-1349.

15. Duffus, J. E., Liu, H. Y., and Wisler, G. C. 1996. Tomato infectious chlorosis virus-A new clostero-like virus transmitted by Trialeurodes vaporariorum. Eur. J. Plant Pathol. 102:219-226.

16. García-Cano, E., Resende, R. O., Boiteux, L. S., Giordano, L. B., Fernández-Muñoz, R., and Moriones, E. 2008. Phenotypic expression, stability, and inheritance of a recessive resistance to monopartite begomoviruses associated with tomato yellow leaf curl disease in tomato. Phytopathology 98:618-627.

17. García-Cano, E., Resende, R. O., Fernández-Munoz, R., and Moriones, E. 2006. Synergistic interaction between Tomato chlorosis virus and Tomato spotted wilt virus results in breakdown of resistance in tomato. Phytopathology 96:1263-1269.

18. Goldbach, R., Bucher, E., and Prins, M. 2003. Resistance mechanisms to plant viruses: An overview. Virus Res. 92:207-212.

19. Jacquemond, M., Verdin, E., Dalmon, A., Guilbaud, L., and Gognalons, P. 2009. Serological and molecular detection of Tomato chlorosis virus and Tomato infectious chlorosis virus in tomato. Plant Pathol. 58:210-220.

20. Jeger, M. J., Holt, J., van den Bosch, F., and Madden, L. V. 2004. Epidemiology of insect-transmitted plant viruses: Modelling disease dynamics and control interventions. Physiol. Entomol. 29:291-304.

21. Jones, R. A. C. 2004. Using epidemiological information to develop effective integrated virus disease management strategies. Virus Res. 100:5-30

22. Jones, R. A. C. 2006. Control of plant virus diseases. Adv. Virus Res. 67:205-244.

23. Jones, R. A. C. 2009. Plant virus emergence and evolution: Origins, new encounter scenarios, factors driving emergence, effects of changing world conditions, and prospects for control. Virus Res. 141:113-130.

24. Lapidot, M., Friedmann, M., Pilowsky, M., Ben Joseph, R., and Cohen, S. 2001. Effect of host plant resistance to Tomato yellow leaf curl virus (TYLCV) on virus acquisition and transmission by its whitefly vector. Phytopathology 91:1209-1213.

25. Lecoq, H., Moury, B., Desbiez, C., Palloix, A., and Pitrat, M. 2004. Durable virus resistance in plants through conventional approaches: a challenge. Virus Res. 100:31-39.

26. Lett, J. M., Hoareau, M., Reynaud, B., Saison, A., Hostachy, B., Lobin, K., and Benimadhu, S. P. 2009. First Report of Tomato chlorosis virus in tomato on Mauritius Island. Plant Dis. 93:111.

27. Liedl, B. E., Lawson, D. M., White, K. K., Shapiro, J. A., Cohen, D. E., Carson, W. G., Trumble, J. T., and Mutschler, M. A. 1995. Acylsugars of wild tomato Lycopersicon pennelli alters settling and reduces oviposition of Bemisia argentifolii (Homoptera: Aleyrodidae). J. Econ. Entomol. 88:742-748.

28. Lindhout, P., Pet, G., and Van der Beek, H. 1994. Screening wild Lycopersicon species for resistance to powdery mildew (Oidium lycopersicum). Euphytica 72:43-49.

29. Lourençao, A. L., Nagai, H, Siqueira, W. J., Usberti Filho, J. A., and
Tavares de Melo, A. M. 1997. Seleção de tomateiros resistentes a tospovírus. Bragantia 56:21-31.

30. Louro, D., Accotto, G. P., and Vaira, A. M. 2000. Occurrence and diagnosis of Tomato chlorosis virus in Portugal. Eur. J. Plant Pathol. 106:589-592.

31. Lozano, G., Moriones, E., and Navas-Castillo, J. 2006. Complete nucleotide sequence of the RNA2 of the crinivirus Tomato chlorosis virus. Arch. Virol. 151:581-587.

32. Lozano, G., Moriones, E., and Navas-Castillo, J. 2007. Complete sequence of the RNA1 of a European isolate of Tomato chlorosis virus. Arch. Virol. 152:839-841.

33. MacDiarmid, R. 2005. RNA silencing in productive virus infections. Annu. Rev. Phytopathol. 43:523-544.

34. Martin, F. W. 1959. Staining and observing pollen tubes in the style by means of fluorescence. Biotech. Histochem. 34:125-128.

35. Martínez-Zubiaur, Y., Fiallo-Olivé, E., Carrillo-Tripp, J., and RiveraBustamante, R. 2008. First report of Tomato chlorosis virus infecting tomato in single and mixed infections with Tomato yellow leaf curl virus in Cuba. Plant Dis. 92:836.

36. Masse, D., Lefeuvre, P., Delatte, H., Abdoul-Karime, A. L., Hostachy, B., Reynaud, B., and Lett, J. M. 2008. Tomato chlorosis virus: First report in Mayotte Island. Plant Pathol. 57:388.

37. Mather, K., and Jinks, J. L. 1982. Biometrical Genetics. 3rd ed. Chapman and Hall, London

38. Moyle, L. C., and Graham, E. B. 2005. Genetics of hybrid incompatibility between Lycopersicon esculentum and L. hirsutum. Genetics 169:355373.

39. Navas-Castillo, J., Camero, R., Bueno, M., and Moriones, E. 2000. Severe yellowing outbreaks in tomato in Spain associated with infections of Tomato chlorosis virus. Plant Dis. 84:835-837.

40. Nettancourt, D. D., Devreux, M., Laneri, U., Cresti, M., Pacini, E., and Sarfatti, G. 1974. Genetical and ultrastructural aspects of self and cross incompatibility in interspecific hybrids between self-compatible Lycopersicon esculentum and self-compatible Lycopersicon peruvianum. Theor. Appl. Genet. 44:278-288.

41. Nombela, G., Beitia, F., and Muñiz, M. 2000. Variation in tomato host response to Bemisia tabaci (Hemiptera: Aleyrodidae) in relation to acyl sugar content and presence of the nematode and potato aphid resistance gene Mi. Bull. Entomol. Res. 90:161-167.

42. Palukaitis, P., and Carr, J. P. 2008. Plant resistance responses to viruses. J. Plant Pathol. 90:153-171.

43. Picken, A. J. F. 1984. A review of pollination and fruit-set in the tomato (Lycopersicon esculentum Mill). J. Hortic. Sci. 59:1-13.

44. Picó, B., Díez, M. J., and Nuez, F. 1999. Improved diagnostic techniques for tomato yellow leaf curl virus in tomato breeding programs. Plant Dis. 83:1006-1012.

45. Reynaud, B., Delatte, H., Peterschmitt, M., and Fargette, D. 2009. Effects of temperature increase on the epidemiology of three major vector-borne viruses. Eur. J. Plant Pathol. 123:269-280.

46. Rick, C. M. 1974. High soluble solids content in large-fruited tomato lines derived from a wild green-fruited species. Hilgardia 42:493-510.

47. Rick, C. M. 1982. The potential of exotic germplasm for tomato improvement. Pages 1-28 in: Plant Improvement and Somatic Cell Genetics. I. K. Vasil, W. R. Scowcroft, and K. J. Frey, eds. Academic Press, New York.

48. Segeren, M. I., Sondahl, M. R., Siqueira, W. J., Medina-Filho, H. P., Nagai, H., and Lourenção, A. L. 1993. Tomato breeding: 1. Embryo rescue of interspecific hybrids between Lycopersicon esculentum Mill. and L. peruvianum (L.) Mill. Rev. Bras. Genet. 16:367-380.

49. Segev, L., Polston, J. E., and Lapidot, M. 2004. First report of Tomato chlorosis virus in Israel. Plant Dis. 88:1160.

50. Tsai, W. S., Shih, S. L., Green, S. K., Hanson, P., and Liu, H. Y. 2004. First report of the occurrence of Tomato chlorosis virus and Tomato infectious chlorosis virus in Taiwan. Plant Dis. 88:311.

51. Van Lenteren, J. C., and Noldus, L. P. J. J. 1990. Whitefly-plant relationships: Behavioural and ecological aspects. Pages 47-89 in: Whiteflies, Their Bionomics, Pest Status and Management. D. Gerling, ed. Intercept Ltd., Andover, Hants, United Kingdom.

52. Verhoeven, J. T. J., Willemen, T. M., Roenhorst, J. W., and van der Vlugt, R. A. A. 2003. First report of Tomato infectious chlorosis virus in tomato in Indonesia. Plant Dis. 87:872.

53. Wintermantel, W. M., Polston, J. E., Escudero, J., and Paoli, E. R. 2001. First report of Tomato chlorosis virus in Puerto Rico. Plant Dis. 85:228.

54. Wintermantel, W. M., and Wisler, G. C. 2006. Vector specificity, host range, and genetic diversity of Tomato chlorosis virus. Plant Dis. 90:814819.

55. Wintermantel, W. M., Wisler, G. C., Anchieta, A. G., Liu, H. Y., Karasev, A. V., and Tzanetakis, I. E. 2005. The complete nucleotide sequence and genome organization of Tomato chlorosis virus. Arch. Virol. 150:22872298. 
56. Wintermantel, W. M., and Zaitlin, M. 2000. Transgene translatability increases effectiveness of replicase-mediated resistance to Cucumber mosaic virus. J. Gen. Virol. 81:587-595.

57. Wisler, G. C., Duffus, J. E., Liu, H. Y., and Li, R. H. 1998. Ecology and epidemiology of whitefly-transmitted closteroviruses. Plant Dis. 82:270-280.

58. Wisler, G. C., Li R., H., Liu, H. Y., Lowry, D. S., and Duffus, J. E. 1998. Tomato chlorosis virus: A new whitefly-transmitted, phloem-limited, bipartite closterovirus of tomato. Phytopathology 88:402-409.

59. Xie, Q., and Guo, H. S. 2006. Systemic antiviral silencing in plants. Virus Res. 118:1-6.

60. Yuan, C., and Ullman, D. E. 1996. Comparison of efficiency and propensity as measures of vector importance in zucchini yellow mosaic potyvirus transmission by Aphis gossypii and A. craccivora. Phytopathology 86:698-703. 